\title{
Students' Numerical Literacy in Solving Islamic-based Problems: Studies on Gender Perspectives
}

\author{
Maria M. Aba ${ }^{1, *}$ Siti P. Anshar, Uke Ralmugiz ${ }^{3}$ \\ 1,2,3 Department of Mathematics Education, Universitas Muhammadiyah Kupang, Indonesia \\ *Corresponding author. Email: martina_aba@unmuhkupang.ac.id
}

\begin{abstract}
Problem-solving is an essential component of mathematics education worldwide. The mathematics curriculum in many countries emphasizes the importance of discussing mathematical problem-solving. Through this aspect, the ability to solve mathematical problems, both routine and non-routine problems, can be investigated. The mindset in solving problems can also be developed by applying problem-solving strategies. The purpose of this study was to analyze the students' mathematical problem-solving ability viewed by gender. This research is descriptive qualitative research. The research subjects consisted of 20 students of class VII at Hidayatullah-Batakte Islamic Boarding School-West Kupang, with 10 male students and 10 female students. Research data was obtained through problem-solving tests and interviews. Data analysis was carried out using three techniques: reducing data, presenting data, and drawing conclusions. The results of this study are 1) there are two categories of problem-solving abilities, namely high and medium;2) based on the number of indicators met by male and female students, it shows that the mathematical problem-solving ability of female students is better than male students. An important finding in this study is that there is an influence of gender on mathematical problem-solving ability, and gender can determine the level of students' mathematical problem-solving ability. This research can be used as a guideline in conducting further research to investigate other factors affecting students' mathematical problem-solving abilities between male and female students.
\end{abstract}

Keywords: Problem-solving, Integrated Islamic, gender, Numerical literacy.

\section{INTRODUCTION}

Problem-solving is an essential component of mathematics education worldwide [1]. The mathematics curriculum in many countries emphasizes the importance of discussing mathematical problem-solving, which is described by the statement that mathematical problemsolving is the general goal of learning mathematics and is even the heart of mathematics. The objectives of learning mathematics described in the National Council of Teachers of Mathematics (NCTM) include several standards, one of which is mathematics as problemsolving [2]. This shows that the ability to solve mathematical problems is an important thing that must be considered in the process of learning mathematics in schools. Then, all students who study mathematics must have and implement problem-solving skills. Mathematical problem-solving ability is the ability to solve routine, non-routine, and applied problems in the field of mathematics [3]. If a problem is considered difficult, problem-solving refers to overcoming difficulties. Thus, good and structured problem-solving skills are needed.
To investigate students' mathematical problemsolving abilities, mathematics tests containing nonroutine problems are often given. Non-routine problems are problems whose solution procedures require completion planning, not just using formulas, theorems, or propositions [3]. Non-routine problems are also problems that are difficult for students to work on and need skills in solving them [4]. In solving non-routine problems, students are expected to be able to identify the elements that are known, asked about and the adequacy of the elements needed, to formulate problems from everyday situations into mathematical form, to apply strategies to solve various problems inside and outside mathematics, to explain or interpret the results according to the original problem, to construct mathematical models and solve them for real problems, and to use mathematics in a meaningful way [5]. In solving problems, previous researchers put forward problemsolving steps. Polya describes four steps for solving mathematical problems, namely 1) understanding the problem (can students state the problems they face in their own words?), 2) designing plans (can students look for patterns or similarities or examine related problems), 3) implementing plans (can students apply problem- 
solving strategies and operations), and 4) looking back (check results) [1]. The facts found in the mathematics learning process are that teachers pay more attention to the final problem-solving results without looking at the problem-solving process itself. This challenges one of the 21st-century mathematics learning objectives which emphasizes problem-solving creativity and can hinder learning objectives in the 2013 curriculum, one of which is to produce students who can develop their creative activities in problem-solving [6].

Another fact shows that most students do not master problem-solving skills. Students have difficulty working on math problems using sentences or story questions, especially students with low math skills [7]. The factors that affect the problem-solving ability of each student are different. This is shown by several previous studies that investigated students' mathematical problem-solving abilities, namely: 1) research on how the ability to solve mathematical problems with Islamic values in Islamic elementary school students found that of the six subjects studied, namely two students with high abilities, two students with the moderate ability, and two students with low ability have differences in solving Islamic nuanced mathematical problems [8]. Thus, it can be concluded that students' mathematical ability affects the way students solve Islamic-values-integrated mathematical problems. The second study is on gender-based comparative research on students' learning outcomes at Madrasah Aliyah Yajri Payaman Magelang, where the classes are separated between boys and girls [9]. The results of the study stated that the comparison of learning outcomes between males and females shows differences, considered from the three educational domains, namely cognitive, affective, and psychomotor. In the cognitive domain, it was found that the average score for male report cards was lower than the average score from their female counterparts. The affective domain shows less striking differences, but women have more affective values than men. For the psychomotor domain, there are significant differences. Men have higher scores and are more active than women. Thus, it can be concluded that gender factors can affect learning outcomes in schools.

In addition to gender, another factor affecting students' problem-solving abilities is the context that appears in the test questions. Students will more easily understand the given problem if the context inserted in the math problem is a context that is often used in everyday life. For madrasa schools such as Islamic boarding schools, the context in math problems can include contexts that contain Islamic values. This is due to the special subjects related to Islam, such as aqidah, fiqh, Arabic, and memorizing or tahfidz of the Qur'an, and there are other lessons in the boarding schools. Islamic values can also be integrated into mathematics learning materials in modules and sample questions. Each material presented is inserted with verses from the Qur'an and Hadith related to the material so that in addition to students gaining mathematics knowledge, they also learn about Islamic religious values at the same time. Suppose Islamic values are inserted in learning, and the learning process is carried out in Islamic educational institutions, such as Islamic boarding schools. In that case, it is very suitable and will make students enthusiastic and easier in learning mathematics. It can also contribute to the goals of Islamic education formulated in The $2^{\text {nd }}$ International Islamic Education Conference. Further, can achieve the ultimate goal of education which lies in its realization, that is, complete surrender to Allah at the level of the individual, community, and humanity [10]. In addition, learning mathematics is also closely related to al-akhlakhul kharimah (good attitude). Al-akhlakul kharimah in this case contains Islamic values [11]. So it is necessary to compile math problems by integrating Islamic values into them.

The fact is that at the Hidayatullah-Batakte Islamic Boarding School, the teachers are still not optimal in providing Islamic-values-integrated mathematics questions in the process of learning and evaluating mathematics learning. Teachers also rarely give story questions in giving math tests. When students are faced with story problems, they have difficulty determining what is known and what is being asked, allowing errors to occur in the problem-solving process. In learning mathematics, story problems for subtraction and addition problems often use the words debt and loan, which indirectly instills the character of borrowing or owed. The teacher does not ask questions using the terms infaq, zakat, or words that contain Islamic values of almsgiving. In this study, in response to the preceeding research, the researchers provided math problems in the form of story questions integrated with Islamic values. The purpose of giving Islamic-integrated mathematics questions to students at Islamic Boarding Schools is to enable students to naturally and unconsciously learn Islamic values. Terms that contain Islamic values are terms that they often read in the Qur'an and they often hear in lectures 
from uztad and uztadzah (the teachers), so this is not a new thing for them. The word Islamic value in the story questions given is not new, but students still often experience difficulties in the problem-solving process.

The descriptions above show that there are factors affecting mathematical problem-solving ability. One of the influencing factors is gender. Thus, the researchers want to investigate further how students' mathematical problem-solving abilities are at the Hidayatullah-Batakte Islamic boarding school where the test questions given are Islamic-integrated mathematics questions that are still rarely applied in this madrasa school. The way to assess and analyze mathematical problem-solving abilities in this study is to use problem-solving indicators according to Polya.

\section{METHODS}

This research was descriptive-qualitative research aiming to describe students' problem-solving ability in solving Islamic-integrated mathematics problems based on gender. This research was conducted at HidayatullahBatakte Islamic Boarding School, Batakte, West Kupang. The subjects of this study were 10 male and 10 female students of class VII at MTS Hidayatullah-Batakte for the academic year 2020/2021. The students were chosen randomly regardless of whether each student had their advantages to meet the needs of the research that would review students' problem-solving abilities from a gender perspective. Because gender differences are not only based on biological differences, but gender also causes differences in male and female brains in structure and their functional background [12]. In addition to differences in brain structure, Elliot et al. summarize gender differences in terms of characteristics, namely physical differences, verbal differences, spatial abilities, mathematical abilities, and learning motivation [12]. In this study, gender differences will be investigated in terms of the characteristics of mathematical abilities.

The research instruments are in the form of Islamicintegrated mathematics problem-solving test questions and interview guidelines. This research began by compiling supporting instruments, namely problemsolving questions and interview guidelines based on the stages of problem-solving ability. The developed test question has been gone through expert validations. After being validated and given suggestions, the researchers then improved the test item instruments and used them in research.

Data examination was carried out when the data had been collected from the completion of the test and ended when compiling the research report. The collected data is then checked and scored according to the problemsolving indicators used in the study. The criteria for the component indicators of problem-solving are presented in Table 1. The categories of mathematical problemsolving abilities are attached in Table 2.
Table 1. The component of problem-solving

\begin{tabular}{|c|c|c|}
\hline No & $\begin{array}{l}\text { The } \\
\text { Component } \\
\text { of PS Ability }\end{array}$ & The indicators of PS Ability \\
\hline 1. & $\begin{array}{l}\text { Understandi } \\
\text { ng the } \\
\text { problem }\end{array}$ & $\begin{array}{l}\text { a) Students are able to } \\
\text { understand the problem by } \\
\text { writing what they know, } \\
\text { asked from the given } \\
\text { problem }\end{array}$ \\
\hline 2. & Make a plan & $\begin{array}{l}\text { a) Students are able to find } \\
\text { appropriate operations for } \\
\text { solving a given problem } \\
\text { b) Students are able to } \\
\text { determine strategies that } \\
\text { can be used in solving } \\
\text { problems. }\end{array}$ \\
\hline 3. & $\begin{array}{l}\text { Solve the } \\
\text { problems } \\
\text { according to } \\
\text { what has } \\
\text { been } \\
\text { planned }\end{array}$ & $\begin{array}{l}\text { a) Students are able to } \\
\text { reinterpret the problems } \\
\text { given in the form of } \\
\text { mathematical sentences. } \\
\text { b) Students can use the } \\
\text { planned completion } \\
\text { strategy }\end{array}$ \\
\hline 4. & Re-checking & $\begin{array}{l}\text { a) Students are able to match } \\
\text { the results obtained with } \\
\text { the questions asked } \\
\text { b) Students are able to } \\
\text { interpret the answers } \\
\text { obtained. } \\
\text { c) Students are able to identify } \\
\text { whether there are other } \\
\text { ways to get a solution to the } \\
\text { problem. } \\
\text { d) Identify whether there are } \\
\text { answers or other results that } \\
\text { meet. }\end{array}$ \\
\hline
\end{tabular}


Table 2. Categories of mathematics problem-solving abilities

\begin{tabular}{|c|c|}
\hline Score & $\begin{array}{c}\text { Categories of mathematical } \\
\text { problem-solving abilities }\end{array}$ \\
\hline $71-100$ & High \\
\hline $41-71$ & Medium \\
\hline $0-40$ & Low \\
\hline
\end{tabular}

In this study, the examination process is carried out using the data analysis technique namely reducing data, presenting data, and drawing conclusions [13].

\section{RESULTS AND DISCUSSION}

The findings are discussed with research questions that aim to describe students' mathematical problemsolving abilities from a gender perspective. There are differences in solving mathematical problems between female and male students. Based on the test from 10 male and female 10 students, the results were obtained in Table 3 and 4. In Table 3, it can be seen that from the 10 male students who took the test, 2 were in the high category with scores obtained are 84 and 78 respectively, while 8 others were in the medium category with scores ranging from 43 to 67 . Then the test results of female students are shown in Table 4 . Of the 10 female students who took the test, 6 were in the high category with scores ranging from 75 to 84 , while 4 others were in the medium category with scores ranging from 63 to 84 .

Table 3. The results of male students' problem solving

\begin{tabular}{|c|c|c|c|}
\hline No & $\begin{array}{c}\text { Students' } \\
\text { name }\end{array}$ & Score & PS category \\
\hline 1 & AA & 78 & High \\
\hline 2 & DAA & 49 & Medium \\
\hline 3 & MN & 64 & Medium \\
\hline 4 & ASS & 63 & Medium \\
\hline 5 & MBH & 67 & Medium \\
\hline 6 & AFP & 51 & Medium \\
\hline 7 & IAA & 43 & Medium \\
\hline 8 & MA & 54 & Medium \\
\hline 9 & KAR & 84 & High \\
\hline 10 & FPR & 54 & Medium \\
\hline
\end{tabular}

Based on the research data, it can be seen that male and female students both meet only two categories, namely high and medium. None is in a low category. Thus it can be concluded that both male and female students have good mathematical problem-solving abilities. The striking thing that distinguishes the problem-solving abilities between male and female students is in terms of score and category achievement. The number of female students in the high category is higher than their male counterparts. However, the achievement of problem-solving indicators from stages 1 to 4 is not much different.

The way of solving the problem and the final result of the solution between male and female students is slightly different. For the high and medium categories, both male and female students passed each stage of problemsolving in a structured manner from the stage of understanding the problem to the stage of planning a solution. However, when solving the problem, female students tend to write the completion process in more detail than male students. After writing the formula that will be used to solve the problem, the female students begin to enter the numbers according to what is known from the problem and calculate. All completion processes are described in detail by female students, compared to male students who only directly write numbers to count, which results in errors in the calculation results because the numbers entered do not match what they want to solve from the given problem. Thus, students are said to have not understood the problem well. Following Polya's principle, students are said to understand the problem when they can understand all the words used to state the problem by determining what is known and what is being asked, and can restate the problem in their own words [14].

When the male students are asked why they were directly entering the numbers and immediately writing

Table 4. The results of female students' problem solving

\begin{tabular}{|c|c|c|c|}
\hline No & $\begin{array}{c}\text { Students' } \\
\text { name }\end{array}$ & Score & PS category \\
\hline 1 & KRD & 66 & Medium \\
\hline 2 & NN & 75 & High \\
\hline 3 & KAS & 74 & Medium \\
\hline 4 & MNL & 84 & High \\
\hline 5 & MH & 75 & High \\
\hline 6 & RI & 80 & High \\
\hline 7 & SA & 63 & Medium \\
\hline 8 & AM & 66 & Medium \\
\hline 9 & HLK & 79 & High \\
\hline 10 & NK & 78 & High \\
\hline
\end{tabular}

the results, they answered that they wanted to finish the work quickly. They also said that the essence of solving problems was to get the correct final result to get a good grade. In contrast to the male students, the female students wrote the process in detail because they thought that the complete process would be assessed and would affect the final result of the assessment. Female students 
were worried that their grades would be low if they did not write down the process in detail. This shows the cause of the differences between men and women in terms of conditions, one of which is behavior. Female students tend to behave according to rules and work more structured because of the anxiety factor, which is higher than male students [15]. Other factors that affect problem-solving abilities in terms of gender are psychological factors related to intelligence, attention, discipline, and readiness [16]. Female students tend to be more disciplined and more attentive, which is indicated by the results of solving problems that are structured according to the stages of problem-solving. In addition, female students are more attentive, indicated by their correct final results, because their attention is focused on test questions. At the stage of re-checking, female students more often re-examine what they have done to make sure whether the answer is correct or not. On the other hand, this stage was not done by male students who reasoned that they did not re-check what they were doing because they wanted to finish it quickly. However, the process that is carried out can reduce the assessment related to indicators of problem-solving ability, mentioning that problem-solving is a thought directed directly to determine solutions to a specific problem [17]. So in the process of problem-solving, directed thinking is needed.

Please note that the problem-solving ability of each student is different. Internal factors that affect students' problem-solving ability include intelligence, motivation, interests, talents, and mathematical abilities, as well as gender differences [18]. However, it does not mean that male students are not able to solve problems well. From the results of the interviews, the male students indicated that they understood the given problem. Still, they preferred to solve the problem directly without having to write down what was known and what was being asked in the early stage of solving the problem. This results in improper troubleshooting. Thus, the difference in solving these problems lies in the way male and female students solve problems [16].

Another thing that is of concern in this study is the problem of integrated problem-solving in Islam. According to the interview, both female students and male students answered that it was not a problem that the questions given were story questions that included Islamic values, because they understood the Islamic context. They hear these contexts every day, both in lectures and in the process of learning special subjects at Hidayatullah-Batakte Islamic Boarding School. Thus, there are no obstacles in the process of solving problems of Islamic-integrated mathematics. However, they said that this was the first time they had Islamic-integrated mathematics problems. Because previously, the math problems often given to them were general math problems, which did not include Islamic contexts. And they feel more interested and easier to understand stories that have context or elements of Islamic values.

\section{CONCLUSION}

Based on the results of the problem-solving test, several things were found to answer the objectives of this study. Regarding the problem-solving ability of Islamicintegrated mathematics in terms of gender, the striking difference between female and male students is in the test results obtained from scores that fall into the category of high problem-solving abilities. The number of female students is higher than that of male students. This shows that the problem-solving abilities of female and male students are different. Several factors are considered to affect the differences in solving problems, which are seen from the different behavior between female and male students. In addition, psychological factors related to intelligence, attention, discipline, and readiness [16] are also considered to affect different problem-solving abilities between female and male students.

Regarding the differences found in the steps of problem-solving process, which are understanding the problem, planning problem solving, solving problems, and reexamining the process, the difference lies in the stage of solving the problem and the stage of reexamining the process. At these two stages, female students tend to be more thorough and detailed in describing and solving problems according to the formula that has been written at the stage of planning a solution. In contrast, male students do not do this. Furthermore, at the reexamining the process, female students did this stage well, which resulted in the correct final result, while male students did not carry out the re-examination stage because they were sure of what was written and wanted to finish it quickly. Thus the gender factor affects problem-solving abilities.

Through this research, it is found that students are attracted and interested in solving Islamic-integrated mathematics problems, because the Islamic contexts contained in the questions are things they often hear and learn every day in the Islamic boarding schools. By providing Islamic-integrated mathematics problems, students better understand the problems to be solved.

\section{AUTHORS' CONTRIBUTIONS}

All authors conceived and designed this study. All authors contributed to the process of revising the manuscript, and in the end, all authors have approved the final version of this manuscript.

\section{REFERENCES}

[1] A.E. Esra, U. Hasan, Investigation of Problem Solving and Problem Posing Abilities of SeventhGrade Students, Educational Science: Theory \& Practice. Turkey, vol. 15(5), Oct. 2015, pp. 1403 1416.

[2] National Council of Teacher Mathematics, Principles and Standards for School Mathematics. Reston, VA:NCTM, 2000. 
[3] L. Karunia, Y. Mokhammad, Penelitian Pendidikan Matematika, Bandung : Refika Aditama, 2017.

[4] L. Riffyanti, R. Setiawan, Analisis Strategi Langkah Mundur dan Bernalar Logis dalam Menentukan Bilangan dan Nilainya, Jurnal Pendidikan Matematika FKIP Universitas Muhammadiyah Metro, 2017, Vol 6 (1). ISSN 2089-8703.

[5] U. Sumarno, Alternatif Pembelajaran Matematika dalam Menerapkan Kurikulum Berbasis Kompetensi, Presented at Seminar Nasional FPMIPA UPI, 2002 : unpublished.

[6] Kemendikbud. 2016. Lampiran 15 Permendikbud Nomor 24. Kompetensi Inti dan Kompetensi Dasar Matematika SMP/MTs. Permendikbud Nomor 24 Tahun, (1), 1-6.

[7] S.M. Alifani, H. Suyitno, Supriyadi, "Mathematical Problem-Solving Abilities Viewed by Intelligence Quotient and Gender Grade $5^{\text {th }}$, Journal of Primary Education. Semarang, vol. 7(1), April 2018, pp.8187.

[8] S. Widodo, Septianiady, R. Puji, Kemampuan Pemecahan Masalah Matematika Bermuatan Nilai Islam, PRISMA, Vol. 9 No. 2, Desember 2020, pp. 192-203.

[9] M, Toriq, Pemisahan Rombongan Belajar Berbasis Gender : Studi Komparatif Hasil Belajar Kelas LakiLaki dan Perempuan di Madrasah Aliyah Yajri Payaman Magelang, Semarang: Fakultas Ilmu Pendidikan Universitas Negeri Semarang, 2017. Unpublished.

[10] A. Abdussalam. Pembelajaran dalam Alquranul Karim," Disertasi, 2017, Bandung : UIN Sunan Gunung Djati.

[11] Abdussakir. Mengintegrasikan Matematika dan Ajaran agama dan Nilai-nilai di Sekolah Dasar dan Menengah, Presented at the $1^{\text {st }}$ International Conference on Mathematics and Islam (ICMIs 2018), Indonesia, 3-5 Agustus 2018.

[12] T. Suendang, Pengaruh Kemampuan Penalaran Matematis Ditinjau dari Perspektif Gender Melalui Pendekatan Open Ended di SMP Patra Mandiri 1 Palembang, undergraduated thesis, UIN Raden Patah, 2017.

[13] A.J. Onwuegbuzie, R.K, Weinbaum, "Mapping Miles and Huberman's Within-Case and Cross-Case Analysis Methods onto the Literature Review Process, Journal of Educational Issues, 2(1), 2016, p. 265.

[14] T.U. Okafor, Effect Of Polya's Problem Solving Technique On The Academic Achievement Of Senior Secondary School Student In Physics,
European J. of Physics Education. Nigeria, Volume 10(1), March 2019, pp. 1309-7202.

[15] N.D. Rodizta, Pengaruh Gender Terhadap Kemampuan Pemecahan Masalah Siswa Kelas VII pada Pokok Bahasan Himpunan Dikontrol dengan Kemampuan Berpikir Kritis Di MTS Darul Amanah, undergraduated thesis, UIN Walisongo, 2019.

[16] Z. Amir, Perspektif Gender dalam Pembelajaran Matematika, Jurnal Marwah. Vol. 12(1), 2013, pp. 14-31. DOI: http://dx.doi.org/10.24014/ marwah.v12i1.511

[17] S. Mawaddah, H. Anisah, Kemampuan Pemecahan Masalah Matematis Siswa Pada Pembelajaran Matematika Dengan Menggunakan Model Pembelajaran Generatif di SMP, Edu-Math: Jurnal Pendidikan Matematika, Vol. 3(2). 2015, pp. 166175.

[18] B. Cahyono, Analisis Keterampilan Berfikir Kritis dalam Memecahkan Masalah Ditinjau Perbedaan Gender, Jurnal Aksioma, 8(1), 2017, pp. 50-64. 